$\pm N$

Global Journals In

(3)

Global JOURnAl OF SCIENCE FRONTIER RESEARCH: C

BIOLOGICAL SCIENCE

Volume 20 Issue 3 Version 1.0 Year 2020

Type : Double Blind Peer Reviewed International Research Journal

Publisher: Global Journals

Online ISSN: 2249-4626 \& Print ISSN: 0975-5896

\title{
"A Clinical Study on the Role of Homoeopathy in Managing Anxiety Disorders in School Going Children of Kanniyakumari District"
}

By Dr. Vineetha Sreekumar \& Dr. Vasanth C Kurup

Sarada Krishna Homoeopathic Medical College

Abstract-Childhood anxiety disorder is one of the emotional disorders which are not due to any abnormalities in brain development or function but improper thoughts and emotions. It has become very common in this world of competition. But these are usually not identified and treated in children. The prime aim of the study is to assess the effective use of individualized Homoeopathic medicines in treating anxiety disorders in school going children of Kanniyakumari district of Tamil Nadu. This study also aims to determine the probable causes and also the type of anxiety disorder prevalent in school-going children. A sample of 30 cases presenting with anxiety disorders was selected using purposive sampling technique from school health programs conducted at Sarada Krishna Homoeopathic Medical College, Kanniyakumari district. Every case is subjected to screening using a basic diagnostic tool Screen for child anxiety related emotional disorders (SCARED), and those cases identified with anxiety disorders will be sent for detailed case taking. Medicine was prescribed according to the individualization and totality of symptoms. The improvement was monitored after 3 to 6 months of prescription by recording the variations in the scoring criteria of the SCARED tool.

Keywords: childhood anxiety disorder, homoeopathic medicine, individualization.

GJSFR-C Classification: FOR Code: 279999

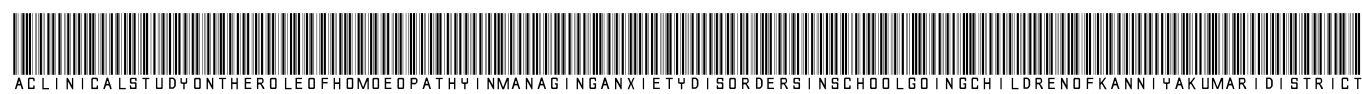

Strictly as per the compliance and regulations of:

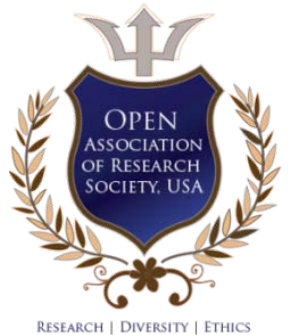

(c) 2020. Dr. Vineetha Sreekumar \& Dr. Vasanth C Kurup. This is a research/review paper, distributed under the terms of the Creative Commons Attribution-Noncommercial 3.0 Unported License http://creativecommons.org/ licenses/by-nc/3.0/), permitting all non commercial use, distribution, and reproduction in any medium, provided the original work is properly cited. 


\title{
A Clinical Study on the Role of Homoeopathy in Managing Anxiety Disorders in School Going Children of Kanniyakumari District
}

\author{
Dr. Vineetha Sreekumar ${ }^{\alpha}$ \& Dr. Vasanth C Kurup ${ }^{\sigma}$
}

\begin{abstract}
Childhood anxiety disorder is one of the emotional disorders which are not due to any abnormalities in brain development or function but improper thoughts and emotions. It has become very common in this world of competition. But these are usually not identified and treated in children. The prime aim of the study is to assess the effective use of individualized Homoeopathic medicines in treating anxiety disorders in school going children of Kanniyakumari district of Tamil Nadu. This study also aims to determine the probable causes and also the type of anxiety disorder prevalent in school-going children. A sample of 30 cases presenting with anxiety disorders was selected using purposive sampling technique from school health programs conducted at Sarada Krishna Homoeopathic Medical College, Kanniyakumari district. Every case is subjected to screening using a basic diagnostic tool Screen for child anxiety related emotional disorders (SCARED), and those cases identified with anxiety disorders will be sent for detailed case taking. Medicine was prescribed according to the individualization and totality of symptoms. The improvement was monitored after 3 to 6 months of prescription by recording the variations in the scoring criteria of the SCARED tool.
\end{abstract}

According to the study result, twelve patients (40\%) have antenatal risk factors, 18 patients $(60 \%)$ have natal risk factors, six patients $(20 \%)$ have environmental risk factors, seven patients $(23.33 \%)$ have developmental delay. Out of the twelve patients, ten of them had antenatal maternal emotional stress as a risk factor. The most commonly identified type of anxiety disorder was social anxiety and separation anxiety disorder. The common co-morbid conditions were learning disability, attention deficit disorder, and nocturnal enuresis. In this study, nine patients (30\%) had marked improvement, ten patients (33.33\%) had moderate and eleven patients (36.66\%) had mild betterness with individualized Homoeopathic medicines. Therefore this medicine can be effectively used as psychologic medicine, which can give emotional healing apart from other systems of medicines as Homoeopathic treatment is based on individualization, i.e treating the person as a whole.

Keywords: childhood anxiety disorder, homoeopathic medicine, individualization.

Author a $\sigma$ : Sarada Krishna Homoeopathic Medical College \& Hospital, Kulasekharam, Kanniyakumari, Tamil Nadu.

Author a: Consultant Physician (Paediatrics), Choorakunnath House, P.C. Kavala P.O, Paippad, Changanassery, Kottayam, Kerala, India.

e-mail: drvineethasreekumar92@gmail.com

Author o: House physician, A.N.S.S. Homoeopathic medical college Hospital, Kottayam, Choorakunnath House, P.C. Kavala P.O, Paippad,

Changanassery, Kottayam, Kerala, India.

e-mail:dr.kurup900@gmail.com

\section{INTRODUCTION}

$\Lambda$ nxiety is a feeling of threat experienced in anticipation of an undesirable event that may be lunknown or specified and is a normal phenomenon (Kleigman, 2015). But when it becomes disabling, causing distress and impairs overall functioning, it is considered as an anxiety disorder (Robin M Murray, 2008). Anxiety disorders can significantly interfere with academic, social, and emotional, and family functioning. The onset of any anxiety disorder was seen in childhood. In different studies of impairing childhood anxiety disorder, $5 \%$ to $13 \%$ of children younger than 18yrs have an anxiety disorder.

a) Need for the study

- Childhood anxiety disorders are the most common type of psychiatric problem in children, which can cause excessive distress, are usually not assessed, diagnosed, and treated properly and if left untreated, can follow a chronic and fluctuating course into adulthood.

- Children experience anxiety just as the adults who can begin at a very early age and is said to be mainly due to the pressures that come from outside sources such as family, friends, or school (Nidhi Luthra, 2007).

- In this competitive world, fear of examination in students is highly increasing. The thought and the pressure to perform well in exams have heightened fear and anxiety and even panic attacks (Rajive Sood, 2004).

- Status of anxiety disorder research from India about management is lacking, and research areas like family studies are not touched.

b) Role of Homoeopathy

The experience of anxiety is unique for each person, and the Homoeopathic approach is personalized, which is a 'holistic' method of diagnosis and of prescription which is called individualization.

Individualized Homoeopathic medicine (IHM) was found effective in reducing the symptoms of anxiety in patients. The current study established the fact that Homoeopathic medicines were very useful in

(n)


psychological medicine (Lakshmipathy R Prabhu, 2012). The anxiolytic effect of the Homoeopathic preparation of Pulsatilla nigricans in Swiss albino mice is proved (S Keerti Jogdand, 2015).

\section{il. Materials and Methods}

\section{a) Study Setting}

A sample of 30 cases presenting with an anxiety disorder was obtained from the school health program conducted by Sarada Krishna Homoeopathic Medical College in Kanyakumari district and also from its outpatient department, and rural centers.

\section{b) Selection of Samples}

A sample of 30 cases presenting with anxiety disorders was selected using a purposive sampling technique. For that, every child will be screened for anxiety disorders using SCARED (screening for childhood anxiety related emotional disorders) diagnostic tool.

\section{c) Inclusion Criteria}

- Patients of pediatric age group between 8yrs to 18yrs

- Children of both sex

- School going children

d) Exclusion Criteria

- Patients taking medicines for any other chronic illness e) Study Design

Interventional before and after treatment without control

\section{f) Brief of Procedures}

Every case is subject to screening using a diagnostic tool, Screen for child anxiety related emotional disorders (SCARED), and those cases identified with anxiety disorders will be sent for detailed case taking. Data was obtained from the patients, bystanders, and physician's observation and the physical examination. Medicine was prescribed according to the individualization and totality of symptoms. The improvement was monitored after 3 to 6 months of administration of medicine by recording the variations in the scoring criteria of the SCARED tool. Pre and post-treatment analysis is done using Screen for child anxiety related emotional disorders (SCARED). Observations are noted in tables and charts. Statistical analysis is done, and results are presented.

\section{g) Data Collection}

Data were obtained from the patient \& bystanders through the interview technique and also from the physician's observation and physical examination. The diagnosis was made through proper screening and assessment of the patient using proper diagnostic tools (SCARED).

\section{h) Statistical Techniques}

- Paired 't' test

i) Statistical Analysis

Table 1: Mean and mean difference of before and after treatment score

\begin{tabular}{|c|c|c|c|c|c|}
\hline SL. No. & $\mathbf{X}$ & $\mathbf{Y}$ & $\mathbf{d}=\mathbf{x}-\mathbf{y}$ & $\mathbf{d}-\underline{\mathbf{d}}$ & $(\mathbf{d}-\underline{\mathbf{d}})^{2}$ \\
\hline 1 & 22 & 12 & 10 & 1.7 & 2.87 \\
\hline 2 & 16 & 9 & 7 & -1.3 & 1.69 \\
\hline 3 & 28 & 18 & 10 & 1.7 & 2.87 \\
\hline 4 & 20 & 7 & 13 & 4.7 & 22.09 \\
\hline 5 & 41 & 22 & 19 & 10.7 & 114.49 \\
\hline 6 & 15 & 9 & 6 & -2.3 & 5.29 \\
\hline 7 & 13 & 9 & 4 & -4.3 & 18.49 \\
\hline 8 & 21 & 13 & 8 & -0.3 & 0.09 \\
\hline 9 & 16 & 13 & 3 & -5.3 & 28.09 \\
\hline 10 & 20 & 14 & 6 & -2.3 & 5.29 \\
\hline 11 & 28 & 13 & 15 & 6.7 & 44.89 \\
\hline 12 & 27 & 18 & 9 & 0.7 & 0.49 \\
\hline 13 & 31 & 24 & 7 & -1.3 & 1.69 \\
\hline 14 & 32 & 18 & 14 & 5.7 & 32.49 \\
\hline 15 & 18 & 12 & 6 & -2.3 & 5.29 \\
\hline 16 & 20 & 11 & 9 & 0.7 & 0.49 \\
\hline 17 & 29 & 20 & 9 & 0.7 & 0.49 \\
\hline 18 & 19 & 8 & 11 & 2.7 & 7.29 \\
\hline 19 & 32 & 23 & 9 & 0.7 & 0.49 \\
\hline 20 & 14 & 11 & 3 & -5.3 & 28.09 \\
\hline 21 & 27 & 21 & 6 & -2.3 & 5.29 \\
\hline 22 & 24 & 15 & 9 & 0.7 & 0.49 \\
\hline
\end{tabular}




\begin{tabular}{|l|l|l|l|l|l|}
\hline 23 & 29 & 16 & 13 & 4.7 & 22.09 \\
\hline 24 & 29 & 17 & 12 & 3.7 & 13.69 \\
\hline 25 & 30 & 16 & 14 & 5.7 & 32.49 \\
\hline 26 & 23 & 20 & 3 & -5.3 & 28.09 \\
\hline 27 & 30 & 26 & 4 & -4.3 & 18.49 \\
\hline 28 & 19 & 16 & 3 & -5.3 & 28.09 \\
\hline 29 & 38 & 33 & 5 & -3.3 & 10.89 \\
\hline 30 & 33 & 29 & 4 & -4.3 & 18.49 \\
\hline
\end{tabular}

$X=$ Score before treatment, $Y=$ Score after treatment, $D=$ Mean difference

Null Hypothesis:

$\sum \mathrm{d}=251$

$\overline{\mathrm{d}}=251 / 30=8.366$

$\sum \mathrm{d}-\overline{\mathrm{d}}=101$

$\sum(d-\bar{d})^{2}=501.06$

Standard error of the mean differences:

The mean of the differences, $d=\Sigma d / n=251 / 30=8.36$

The estimate of population standard deviation is given by,

$$
\begin{aligned}
\mathrm{SD} & =\sqrt{\Sigma(\mathrm{d} 1-\overline{\mathrm{d}} 1)^{2}} / \mathrm{n}-1 \\
& =\sqrt{501.06 / 29}= \\
& =\sqrt{17.22}=4.149
\end{aligned}
$$

The estimate of standard error of mean, Standard error (S.E)

$$
=\mathrm{S} \cdot \mathrm{D} / \sqrt{n}=4.149 / \sqrt{30}=0.757531495
$$

The test statistics is Paired $t$ :

Critical ratio, $t=\frac{\bar{d}}{S . D / \sqrt{n}}=8.366 / 0.757531495=11.043$

Table 2: t-Test: Paired Two Sample for Means

\begin{tabular}{|l|c|c|}
\hline & Variable 1 & Variable 2 \\
\hline Mean & 24.8 & 16.43333 \\
Variance & 51.68276 & 40.59885 \\
Observations & 30 & 30 \\
Pearson Correlation & 0.818731 & \\
Hypothesized Mean Difference & 0 & \\
df & 29 & \\
t Stat & 11.02574 & \\
$\mathrm{P}(T<=$ t) one-tail & $3.44 \mathrm{E}-12$ & \\
t Critical one-tail & 1.699127 & \\
$\mathrm{P}(T<=$ t) two-tail & $6.88 \mathrm{E}-12$ & \\
t Critical two-tail & 2.04523 & \\
\hline
\end{tabular}

Interpretation of results:

- Comparison with the tabled value:

On comparing the score before and after treatment, the means were 24.8 and 16.43333 and the variances were 51.68276, and 40.59885 respectively (Table 1, Table 2). The data showed a positive correlation of 0 . Since the calculated value is greater than the tabled value at $5 \%$ and $1 \%$, the null hypothesis was rejected at $95 \%$ significance and the hypothesis that Homoeopathy is effective in treating anxiety disorders in children is accepted.

j) Data Analysis

Data presentation including charts and tables 
Table 3: Distribution of cases according to age

\begin{tabular}{|c|c|c|}
\hline Age & Number of Patients & Percentage \\
\hline $6-8$ & 12 & 40 \\
\hline $9-11$ & 9 & 30 \\
\hline $12-14$ & 6 & 20 \\
\hline $15-17$ & 3 & 10 \\
\hline
\end{tabular}

Table 4: Distribution of cases according to probable risk factors

\begin{tabular}{|c|c|c|c|c|c|}
\hline $\begin{array}{c}\text { Probable Risk } \\
\text { Factors }\end{array}$ & $\begin{array}{c}\text { Antenatal } \\
\text { Causes }\end{array}$ & $\begin{array}{c}\text { Natal } \\
\text { Causes }\end{array}$ & $\begin{array}{c}\text { Environmental } \\
\text { (At Home \& } \\
\text { School) }\end{array}$ & $\begin{array}{c}\text { Developmental } \\
\text { Delay }\end{array}$ & $\begin{array}{c}\text { Unknown } \\
\text { Causes }\end{array}$ \\
\hline $\begin{array}{c}\text { Number Of } \\
\text { Patients }\end{array}$ & 12 & 18 & 6 & 7 & 6 \\
\hline Percentage & 40 & 60 & 20 & 23.33 & 20 \\
\hline
\end{tabular}

Table 5: Distribution of cases according to screening with the SCARED tool

\begin{tabular}{|c|c|c|c|c|c|c|c|}
\hline Score & $10-15$ & $16-20$ & $21-25$ & $26-30$ & $31-35$ & $36-40$ & $\mathbf{4 1 - 4 5}$ \\
\hline No. Of Patients & 3 & 8 & 4 & 9 & 4 & 1 & 1 \\
\hline Percentage & 10 & 26.66 & 13.33 & 30 & 13.33 & 3.33 & 3.33 \\
\hline
\end{tabular}

Table 6: Distribution of cases according to the type of anxiety disorder

\begin{tabular}{|c|c|c|}
\hline Type of anxiety disorder & Number of patients & Percentage \\
\hline Generalized Anxiety Disorder (GD) & 3 & 10 \\
\hline Separation Anxiety Disorder (SP) & 23 & 76.66 \\
\hline Social Anxiety Disorder (SC) & 25 & 83.33 \\
\hline Panic Disorder (PD) & 5 & 16.66 \\
\hline Significant School Avoidance (SH) & 5 & 16.66 \\
\hline
\end{tabular}

Table 7: Distribution of cases according to co-morbidity of anxiety disorders in children

\begin{tabular}{|l|c|c|}
\hline \multicolumn{1}{|c|}{ Co-morbidity } & Number of Patients & Percentage \\
\hline ADHD & 3 & 10 \\
\hline Epilepsy & 2 & 6.66 \\
\hline Intellectual Disability & 4 & 13.33 \\
\hline Learning Disability & 7 & 23.33 \\
\hline Attention Deficit Disorder & 5 & 16.66 \\
\hline Oppositional Defiant Disorder & 1 & 3.33 \\
\hline Nocturnal Enuresis & 5 & 16.66 \\
\hline Cerebral Palsy & 2 & 6.66 \\
\hline
\end{tabular}

Table 8: Distribution of cases according to the remedy prescribed

\begin{tabular}{|l|c|c|}
\hline Remedy prescribed & Number of patients & Percentage \\
\hline Lycopodium clavatum & 2 & 6.66 \\
\hline Carcinosinum & 2 & 6.66 \\
\hline Calcarea carbonica & 4 & 13.33 \\
\hline Cuprum metalicum & 1 & 3.33 \\
\hline Tuberculinum & 1 & 3.33 \\
\hline Silicea terra & 3 & 10 \\
\hline Calcarea phoshorica & 4 & 13.33 \\
\hline Natrum muriaticum & 3 & 10 \\
\hline
\end{tabular}




\begin{tabular}{|l|c|c|}
\hline Phosphorous & 4 & 13.33 \\
\hline Tarantula & 1 & 3.33 \\
\hline Arsenicum album & 2 & 6.66 \\
\hline Opium & 1 & 3.33 \\
\hline Baryta carbonica & 1 & 3.33 \\
\hline Natrum sulphuricum & 1 & 3.33 \\
\hline
\end{tabular}

Table 9: Distribution of cases according to the improvement in the anxiety disorder

\begin{tabular}{|c|c|c|c|}
\hline & $\begin{array}{c}\text { Mild } \\
\text { Improvement }\end{array}$ & $\begin{array}{c}\text { Moderate } \\
\text { Improvement }\end{array}$ & $\begin{array}{c}\text { Marked } \\
\text { Improvement }\end{array}$ \\
\hline Number of patients & 11 & 10 & 9 \\
\hline Percentage & 30 & 33.33 & 36.66 \\
\hline
\end{tabular}

\section{Results}

a) Distribution of cases according to age

Out of thirty cases, twelve patients $(40 \%)$ were of age 6 to 8 years old, nine patients (30\%) were of age 9 to 11 years old, six patients (20\%) were of age 12 to 14 years old, and three patients (10\%) were of age 15 to 17 years old.

b) Distribution of cases according to probable risk factors

Out of 30 cases, twelve patients (40\%) have antenatal risk factors, eighteen patients $(60 \%)$ have natal risk factors, six patients $(20 \%)$ have environmental risk factors, seven patients (23.33\%) have developmental delay and six patients (20\%) have unknown probable risk factors. c) Distribution of cases according to antenatal risk
factors

Out of 30 cases, twelve patients (40\%) have antenatal risk factors. Out of the twelve patients, ten of them had antenatal maternal emotional stress as a risk factor.

d) Distribution of cases according to screening with the children with anxiety-related emotional disorders (SCARED) tool

Out of 30 patients, three patients (10\%) had the score range from $10-15$, eight patients $(26.66 \%)$ had the score between $16-20$, four patients (13.33\%) had the score range from $21-25$, nine patients $(30 \%)$ had score 26 - 30, four patients (13.33\%) had score $31-35$, one patient (3.33\%) had score between 36 - 40, and one patient (3.33\%) had score between $41-45$.

\section{e) Distribution of cases according to the type of anxiety disorder}

Out of 30 cases, twenty five patients (83.33\%) had social anxiety, twenty three patients (76.66\%) had separation anxiety, five patients (16.66\%) had panic disorder, five patients (16.66\%) presented with significant school avoidance, and three patients (10\%) had a generalized anxiety disorder. f) Distribution of cases according to co-morbidity of anxiety disorders in children

Out of 30 patients, three patients (10\%) had attention deficit hyperactivity disorder (ADHD), two patients (6.66\%) had epilepsy, four patients (13.33\%) had intellectual disability, seven patients $(23.33 \%)$ had learning disability, five patients (16.66\%) had attention deficit disorder, one patient (3.33\%) had oppositional defiant disorder, five patients (16.66\%) had nocturnal enuresis, and two patients (6.66\%) had cerebral palsy.

g) Distribution of cases according to the remedy prescribed

Out of 30 cases, two patients were given Lycopodium clavatum, two patients with Carcinosinum, four patients were given Calcarea Carbonica, one patient with Cuprum metallicum, one patient with Tuberculinum, three patients with Silicea terra, four patients with Calcarea phosphorica, three patients with Natrum muriaticum, four patients with Phosphorous, one patient with Tarentula, two patients with Arsenicum album, one patient with Opium, one patient with Baryta carbonica, and one patient were given Natrum sulphuricum.

h) Distribution of cases according to the improvement in the anxiety disorder

Out of 30 cases, 9 patients (30\%) had marked improvement, 10 patients (33.33\%) had moderate improvement and 11 patients (36.66\%) had mild improvement.

\section{Discussion}

In the study, out of 30 cases, twelve patients (40\%) were of age 6 to 8 years old, nine patients (30\%) were of age 9 to 11 years old, six patients $(20 \%)$ were of age 12 to 14 years old, and three patients (10\%) were of age 15 to 17 years old. Therefore commonly affected age group was 6 to 8 years (Table 3, Figure 1). 


\section{DISTRIBUTION ACCORDING TO AGE}

\section{× AGE $\approx$ PERCENTAGE}

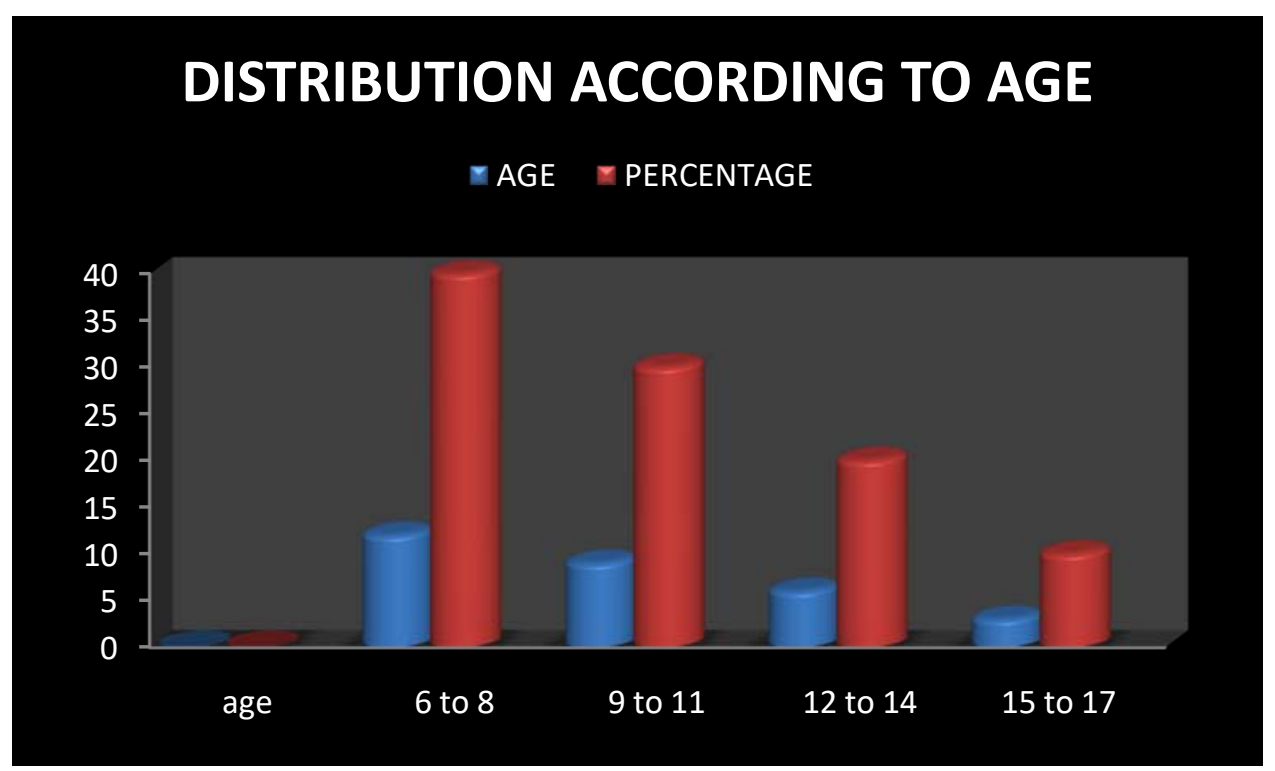

Figure 1: Distribution of cases according to age

There was no gender difference, according to this study. Among the 30 cases, fifteen patients (50\%) were females and the fifteen patients (50\%) were males.

Out of 30 cases, twelve patients (40\%) have antenatal risk factors, eighteen patients $(60 \%)$ have natal risk factors, six patients (20\%) have environmental risk factors, seven patients (23.33\%) have developmental delay and, six patients (20\%) have unknown probable risk factors. Out of the twelve patients with antenatal risk factors, ten of them had antenatal maternal emotional stress as a risk factor (Table 4, Figure 2).

\section{DISTRIBUTION ACCORDING TO ANTENATAL RISK FACTORS}

m antenatal maternal emotional stress $\mathrm{m}$ other antenatal maternal causes m causes other than antenatal factors

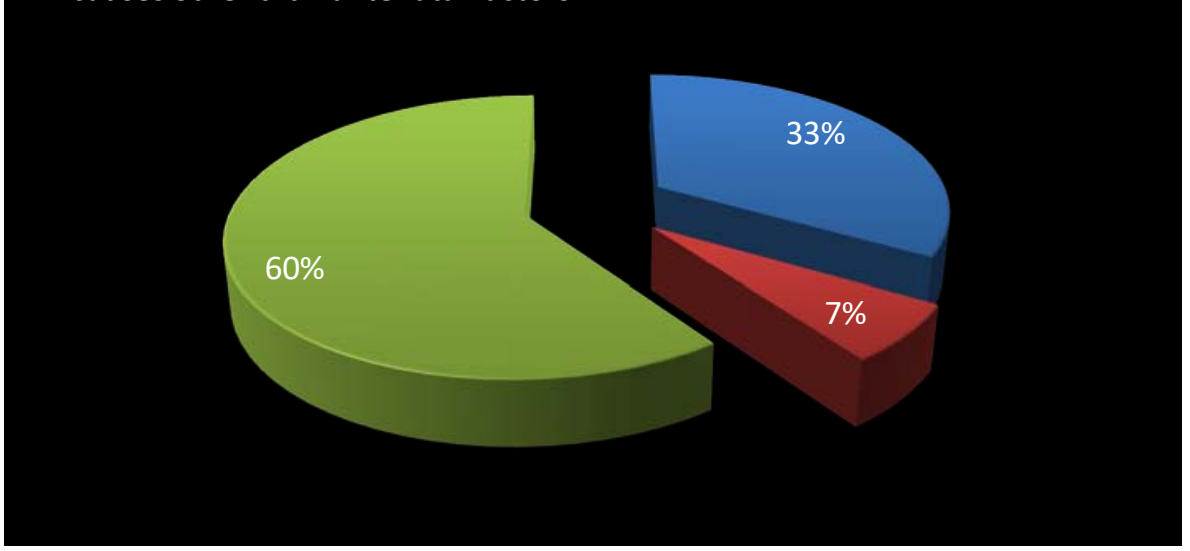

Figure 2: Distribution according to antenatal risk factors

Environmental risk factors like parenting style, childhood adversities, relationship stress, etc. were found to be associated with anxiety disorder. Nearly $20 \%$ of women suffer from mental health disorders during gestation. $5.12 \%$ had anxiety and $6.69 \%$ were having anxiety, and depression (De Mond $M$ Grant, 2013). In the study, $60 \%$ of cases have natal risk factors, and $40 \%$ have antenatal risk factors, and $20 \%$ have developmental delay as risk factor than environmental causes, which is $23.33 \%$. Also, antenatal maternal stress is found to be another important antenatal risk factor where further research is required.

Out of 30 patients, three patients (10\%) had the score range from $10-15$, eight patients $(26.66 \%)$ had the score between $16-20$, four patients $(13.33 \%)$ had the score range from $21-25$, nine patients $(30 \%)$ had score 26 - 30, four patients (13.33\%) had score $31-35$, one patient (3.33\%) had score between $36-40$, and one 
patient (3.33\%) had score between 41 - 45 (Table 5). The tool consists of 41 items and five factors that parallel the DSM -IV classification of anxiety disorders. In this study, many patients had specific social phobias. But these couldn't be assessed using the SCARED tool, which were generally considered as social phobia.
Out of 30 cases, twenty five patients (83.33\%) had social anxiety, twenty three patients (76.66\%) had separation anxiety, five patients (16.66\%) had panic disorder, five patients (16.66\%) presented with significant school avoidance, and three patients (10\%) had a generalized anxiety disorder (Table 6, Figure 3).

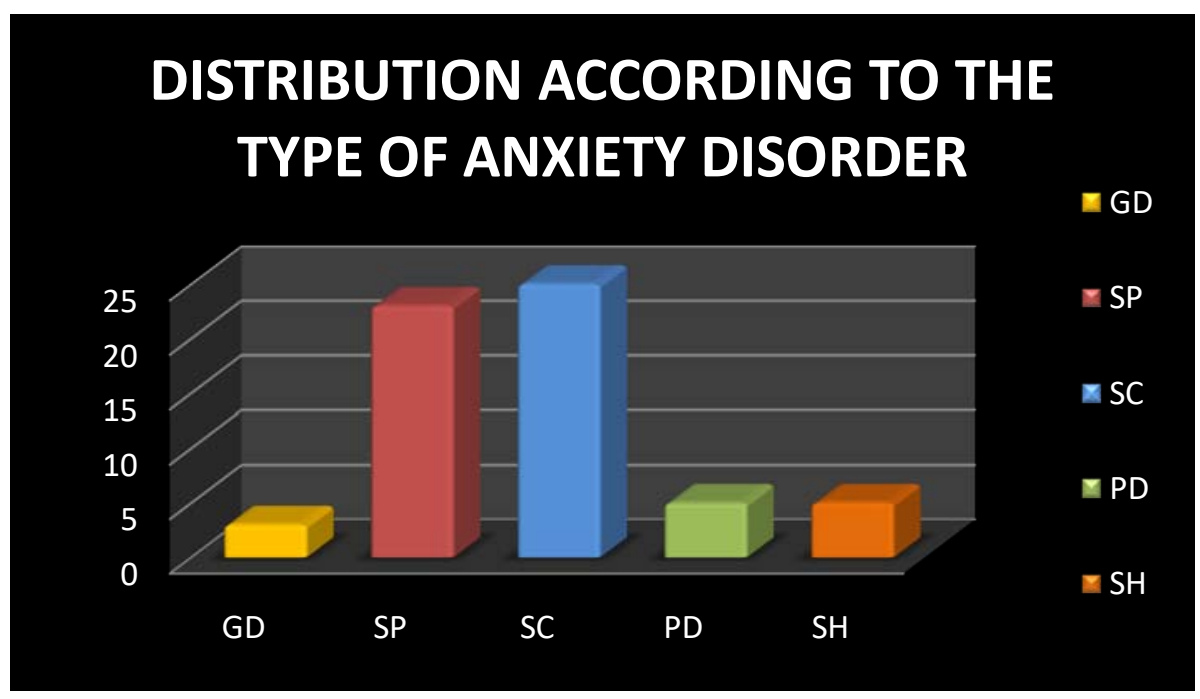

Figure 3: Distribution according to the type of anxiety disorder

The most commonly identified type of anxiety disorder was social anxiety, which includes specific social phobias, and separation anxiety disorder. An inter anxiety co-morbidity was seen in most of the cases.

The majority of the cases have a learning disabilities, attention deficit disorder, and nocturnal enuresis. Other co-existing conditions were attention deficit hyperactivity disorder, epilepsy, intellectual disability, oppositional defiant disorder, and cerebral palsy (Table 7, Figure 4). In most of the cases, these comorbid conditions can be a causative or risk factor of anxiety disorder. Therefore managing anxiety disorders can also improve the co-morbid conditions simultaneously.

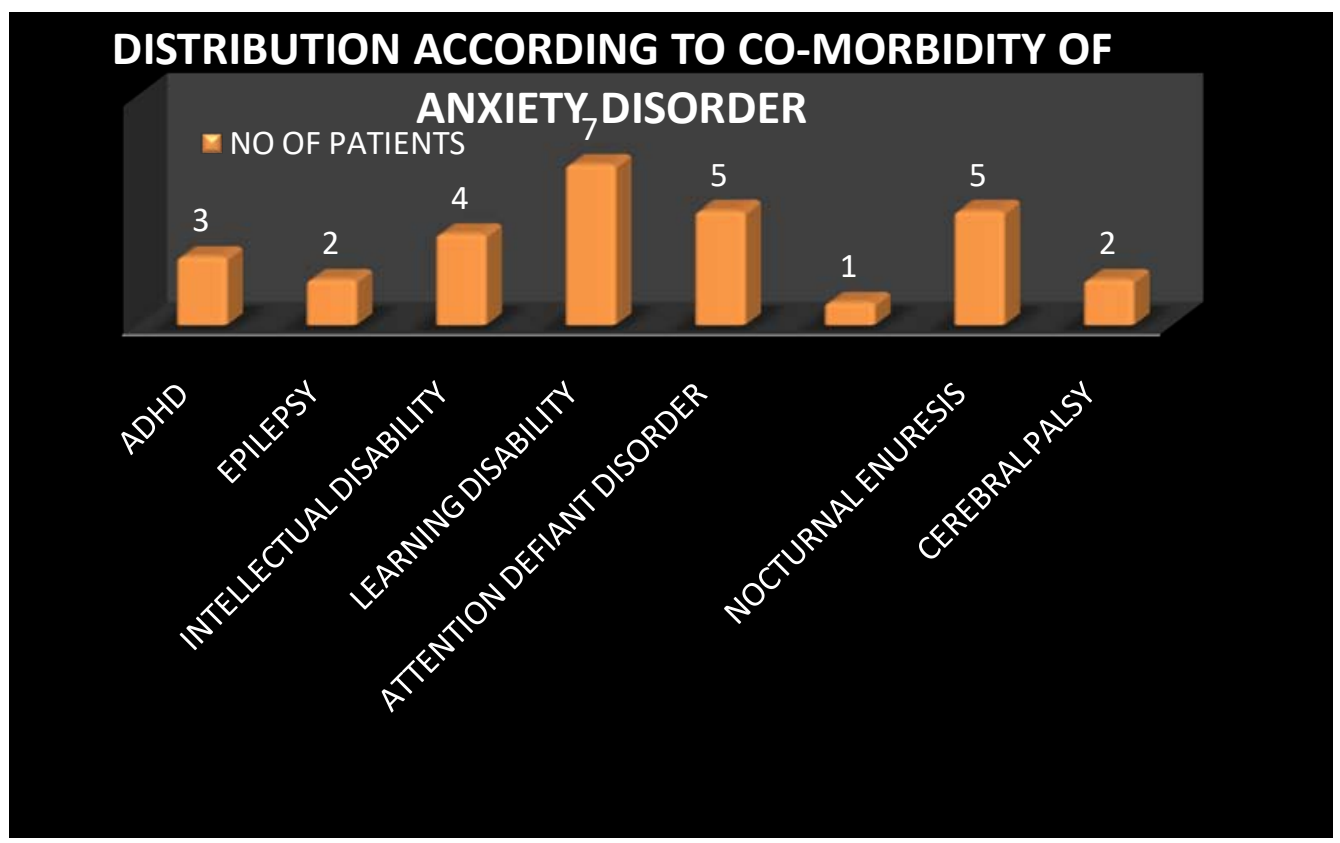

Figure 4: Distribution according to co-morbidity of anxiety disorder

Out of 30 cases, two patients were given Lycopodium clavatum, two patients with Carcinosinum, four patients were given Calcarea Carbonica, one patient with Cuprum metallicum, one patient with Tuberculinum, three patients with Silicea terra, four patients with Calcarea phosphorica, three patients with 
Natrum muriaticum, four patients with Phosphorous, one patient with Tarentula, two patients with Arsenicum album, one patient with Opium, one patients with Baryta carbonica, and one patient was given Natrum sulphuricum. According to the remedy analysis, the individualized Homoeopathic medicines are effective in managing anxiety disorders in children. Among these medicines, Calcarea Carbonica, Calcarea phosphorica, and Phosphorus are the mostly used remedies (Table 8). The improvement is assessed after a duration of 3 6months after Homoeopathic treatment using individualized Homoeopathic medicines.

Out of 30 cases, nine patients $(30 \%)$ had marked improvement, ten patients (33.33\%) had moderate improvement, and eleven patients (36.66\%) had mild improvement (Table 9, Figure 5).

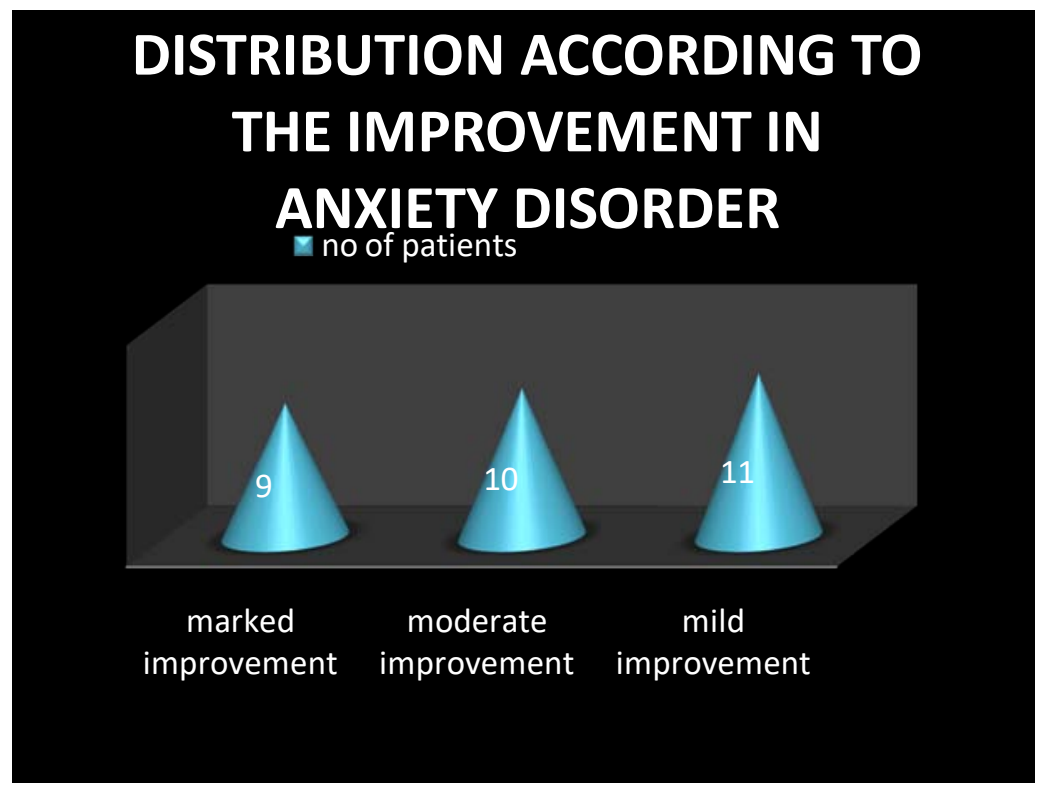

Figure 5: Distribution according to the improvement in anxiety disorder

\section{Conclusion}

The following conclusions are drawn from the study:

- The majority of patients belong to age groups $6-8$ years (40\%) and $9-11$ years (30\%).

- There is no sex difference according to the study's prevalence of anxiety disorders in children.

- Out of 30 patients, the number of patients from average socio-economic status was fourteen (46.66\%), from below-average socio-economic status were three $(10 \%)$, and above-average socioeconomic status were thirteen (43.33\%).

- In the study the probable risk factors identified were antenatal, natal, environmental and developmental delay as risk factors. Twelve patients (40\%) have antenatal risk factors, eighteen patients (60\%) have natal risk factors, six patients (20\%) have environmental risk factors, seven patients (23.33\%) have developmental delay and, six patients (20\%) have unknown probable risk factors. Out of 30 cases, twelve patients (40\%) have antenatal risk factors. Out of the twelve patients, ten of them had antenatal maternal emotional stress as a risk factor.

- The majority of patients had a score $26-30$ and 16 -20 with a percentage $30 \%$ and $26.66 \%$, respectively.
- The type of anxiety disorder more prevalent in the study was social anxiety and separation anxiety disorder, with a percentage of $83.33 \%$ and $76.66 \%$, respectively.

- The most common co-morbidity identified in the study was learning disability (23.33), attention deficit disorder (16.66\%), and nocturnal enuresis (16.66\%).

- The Individualized Homoeopathic medicine was given, and the mostly used remedies were Calcarea carbonica, Calcarea phosphorica, and Phosphorus.

- The concept of disease in Homoeopathy is of prime importance in the Homoeopathic system. It stresses the importance of individuality of a person as a whole.

- Results of the study suggest that the individualistic approach of Homoeopathy was found effective in the management of anxiety disorders in school going children. Also, studies have proven that Homoeopathic medicines are effective as Psychological medicine.

\section{References Références Referencias}

1. M Denise Goodman, Kleigman, Stanton, St.Geme, Shor, Behrman. Nelson textbook of paediatrics $18^{\text {th }}$ edition, Page No: 117-120, Elsevier New Delhi 
2. Murray, Kendler, Mc Guffin, Wessely, Castle. Essential psychiatry $4^{\text {th }}$ edition, Page No: 147. Cambridge university press

3. Nidhi Luthra, Homoeopathy for all. Get the stress out of children. Volume 8. No.7 (50). July 15 2007, Page No: 38 - 44

4. Rajive Sood, Homoeopathy for all. Dealing with examination stress; Volume 5 No2 (50) Feb15 2004; Page No: 43- 45

5. Lakshmipathy R Prabhu. Homeopathy. Anxiolytic effect of homoeopathic preparation of Pulsatilla nigricans in Swiss albino mice; Volume 101, Issue 3, July 2012, Page No: $171-174$

6. S Keerti Jogdand, N Pravin Yerpude; A cross sectional study on social factors responsible for mental morbidity among pregnant women. Innovative Journal of mental and health science5. 4 July- August (2015). Page No: 159-161

7. https://www.researchgate.net/publication/23685137 7/ De Mond M Grant/ anxiety in adolescence/ Chapter- May 2013, Page No: 509, 510

\section{ApPENDIX}

Screen For Child Anxiety Related Emotional Disorders (Scared)

\begin{tabular}{|c|c|c|c|}
\hline & $\begin{array}{c}0 \\
\text { Not true or } \\
\text { hardly ever } \\
\text { true }\end{array}$ & $\begin{array}{c}1 \\
\text { Somewhat true } \\
\text { or sometimes } \\
\text { true }\end{array}$ & $\begin{array}{c}2 \\
\begin{array}{c}\text { Very true or often } \\
\text { true }\end{array}\end{array}$ \\
\hline $\begin{array}{l}\text { 1. When I feel frightened, it is hard to } \\
\text { breath }\end{array}$ & & & \\
\hline 2. I get headache when I am at school & & & \\
\hline $\begin{array}{l}\text { 3. I don't like to be with people I don't } \\
\text { know well }\end{array}$ & & & \\
\hline $\begin{array}{l}\text { 4. I get scared if I stay away from } \\
\text { home }\end{array}$ & & & \\
\hline $\begin{array}{l}\text { 5. I worry about other people liking } \\
\text { me }\end{array}$ & & & \\
\hline $\begin{array}{l}\text { 6. When I get frightened, I feel like } \\
\text { passing out }\end{array}$ & & & \\
\hline 7. I am nervous & & & \\
\hline $\begin{array}{l}\text { 8. I follow my mother or father } \\
\text { wherever I go }\end{array}$ & & & \\
\hline 9. People tell me that I am nervous & & & \\
\hline $\begin{array}{l}\text { 10. I feel nervous with people I don't } \\
\text { know }\end{array}$ & & & \\
\hline 11. I get stomachaches at school & & & \\
\hline $\begin{array}{l}\text { 12. When I get frightened I feel like I am } \\
\text { going crazy }\end{array}$ & & & \\
\hline 13. I worry about sleeping alone & & & \\
\hline $\begin{array}{l}\text { 14. I worry about being as good as } \\
\text { other kids }\end{array}$ & & & \\
\hline $\begin{array}{l}\text { 15. When I get frightened, I feel like } \\
\text { things are not real }\end{array}$ & & & \\
\hline $\begin{array}{l}\text { 16. I have nightmares about something } \\
\text { bad happening to parents }\end{array}$ & & & \\
\hline 17. I worry about going to school & & & \\
\hline $\begin{array}{l}\text { 18. When I get frightened, my heart } \\
\text { beats fast }\end{array}$ & & & \\
\hline 19. I get shaky & & & \\
\hline $\begin{array}{l}\text { 20. I have nightmares of something } \\
\text { bad happening to me }\end{array}$ & & & \\
\hline $\begin{array}{l}\text { 21. I worry about things working about } \\
\text { me }\end{array}$ & & & \\
\hline 22. When I get frightened, I sweat a lot & & & \\
\hline 23. I am a worrier & & & \\
\hline $\begin{array}{l}\text { 24. I really get frightened for no reason } \\
\text { at all }\end{array}$ & & & \\
\hline
\end{tabular}




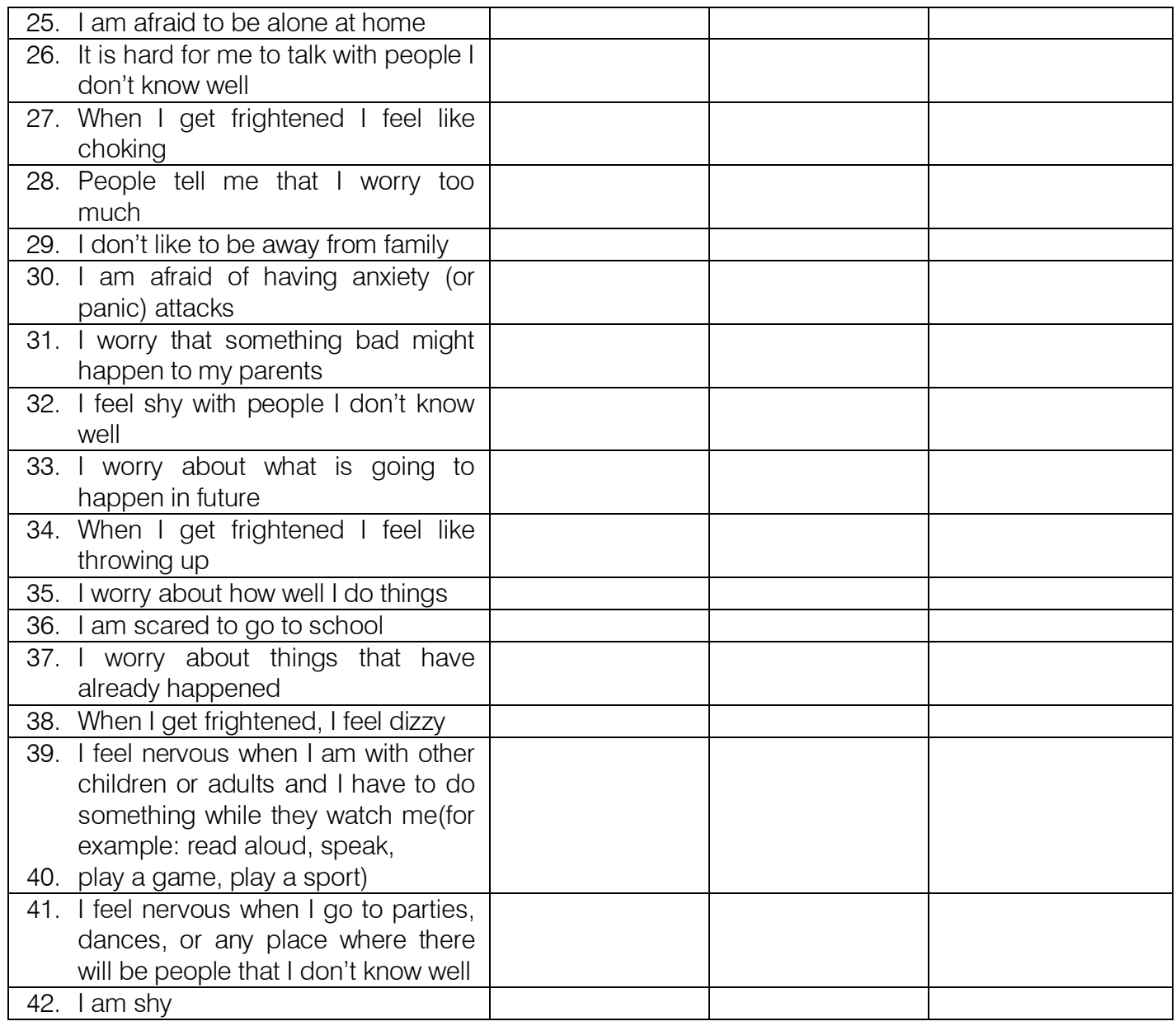

Scoring:

A total score of $\geq 25$ may indicate the presence of an Anxiety Disorder. Scores higher than 30 are more specific. TOTAL $=$

A score of 7 for items 1, 6, 9, 12, 15, 18, 19, 22, 24, 27, 30, 34, 38 may indicate Panic Disorder or Significant Somatic Symptoms. $\mathrm{PN}=$

A score of 9 for items 5, 7, 14, 21, 23, 28, 33, 35, 37 may indicate Generalized Anxiety Disorder. GD =

A score of 5 for items 4, 8, 13, 16, 20, 25, 29, 31 may indicate Separation Anxiety SOC. SP =

A score of 8 for items 3, 10, 26, 32, 39, 40, 41 may indicate Social Anxiety Disorder. SC =

A score of 3 for items 2, 11, 17, 36 may indicate Significant School Avoidance. SH = 